ELENA CRAȘOVAN

\title{
MAGICAL REALISM AVATARS IN THE ROMANIAN NOVEL
}

Phases of Magical Realist Literature and the Distribution of Romanian Novels Therein

Almost one century after magical realism made its way into literary criticism debates and in "the world republic of letters" (to use Pascale Cassanova's groundbreaking 2007 term), it is still a phenomenon of interest for researchers. For it proves to be malleable enough, always ready to mutate and associate with no matter what topically new directions (modernism, postmodernism, postcolonialism), capable to cross a great variety of geographical and cultural spaces ranging from interwar Europe to Latin America, subsequently exported to postcolonial Asia and Africa after the Latin-American boom, and sweeping the stage in many a Western capital city, as well as in the countries of the former communist bloc. It is one of the most productive critical concepts to date; the success with literary critics and readers alike of such emblematic writers as Márquez, Rushdie, Morrison has granted its presence in brilliant world literature volumes of the last decades ${ }^{1}$ : it features as an exemplary world literature genre, always ready for new attachments and interconnections at every turn, conducive to fresh "constellations of texts whose identity is defined in accordance with new needs and new critical and aesthetic desires translated into new organizing principles"2. Naturally, the resulting genre attracts a distinct poetics, crossculturally recognizable in a significant part of the fictional creations ranging from the twentieth century to the present. We can consequently propose that there are three magical realism phases in world literature, each with distinct theoretical premises of its own, as well as with specific historical, regional, and stylistic features. Early magical realism appeared in Europe in the period following the First World War; it was followed by the Latin-American boom, and, thirdly, by the postcolonial and post-communist expansion.

In what follows, we alternate the chronological and typological perspectives with a view to grouping the magical realist accents which appeared in the Romanian novel, making our way through some re-readings, in this key, of fiction

\footnotetext{
${ }^{1}$ Franco Moretti (ed.), The Novel, vol. I: History, Geography and Culture, Princeton, Princeton University Press, 2006; Theo D'haen, David Damrosch, Djelal Kadir (eds.), The Routledge Companion to World Literature, London - New York, Routledge, 2012; Marcel Cornis-Pope and John Neubauer (eds.), History of the Literary Cultures of East-Central Europe. Junctures and Disjunctures in the 19th and 20th Centuries, vol. I, Amsterdam - Philadelphia, John Benjamins Publishing Company, 2004.

${ }^{2}$ Mariano Siskind, “The Genres of World Literature. The Case of Magical Realism”, in Theo D'haen, David Damrosch, Djelal Kadir (eds.), The Routledge Companion to World Literature, p. 347.
} 
written in the previous century, and connecting the publications in our country with the global tendencies that configure the history of the genre.

Although the theoretical approaches to magical realism in Romanian literature cannot possibly match the wide range of the Anglo-Saxon discussions of this subject $^{3}$, we can safely assimilate to this trend a number of fictional titles by Mihail Sadoveanu and Vasile Voiculescu, whose fascination for the archaic and esotericism and whose re-writing of history in the light of myth may well be placed side by side with the novels by Massimo Bontempelli or Ernst Jünger.

Though interwar literature examples of magical realism are present as rather isolated flashes, Romanian fiction of this type features as a distinct direction in the 1960s and 1970s - under the direct Latin-American influence. But there is more than mimesis in the novels published by Ştefan Bănulescu, D.R. Popescu, George Bălăiță or Sorin Titel; they are primarily reactions to the communist domination of socialist realism. It is worth noting that after their initial evasionist tendencies, the magical realist novels of these writers acquired subversive notes, which caused distinct ironical and grotesque accents and brought Romanian literature close to a lot of the Central-European literature of the period in reaction to the communist regime's oppression ${ }^{4}$. Next, the members of the Romanian 1980s generation, Ștefan Agopian, Mircea Nedelciu, Ioan Groșan, stand out through the symbiosis of their new formula of magical realism with textualist techniques and their tendency to adopt postmodernist techniques: historiographic metafiction, covert and unstable irony, multiple narrative threads.

The novels published in post-communism represent a third distinct phase. Just as in the West the association of magical realism with postcolonial studies has had a favourable effect on the reception of writers from the former Commonwealth, in Central European, and especially in Romanian culture we can speak, in novels by Mircea Cărtărescu, Doina Ruști, Bogdan Popescu, Radu Pavel Gheo, Tudor Ganea, of certain characteristic magical realist themes and motifs: historical atrocities are re-inscribed at the juncture of official discourse and individual experience; the outlook of the marginals predominates; irony and grotesque presentations abound.

\footnotetext{
${ }^{3}$ Among the fundamental titles in the vast literature that document the phenomenon are: Amaryll Chanady, Magical Realism and the Fantastic. Resolved Versus Unresolved Antinomy, New York, Routledge, 1985; Lois Parkinson Zamora and Wendy B. Faris (eds.), Magical Realism. Theory, History, Community, Durham - London, Duke University Press, 1995; Roberto Gonzáles Echevarría, Myth and Archive. A Theory of Latin American Narrative, Durham - London, Duke University Press 1998; Jean Pierre Durix, Mimesis, Genres and Postcolonial Discourse: Deconstructing Magic Realism, London, Palgrave MacMillan, 1998; Wendy B. Faris, Ordinary Enchantments: Magical Realism and the Remystification of Narrative, Nashville, Vanderbilt University Press, 2004; Christopher Warnes, Magical Realism and the Postcolonial Novel: between Faith and Irreverence, London, Palgrave MacMillan, 2009; Eugene L. Arva, The Traumatic Imagination: Histories of Violence in Magical Realist Fiction, Amherst, Cambria, 2011.

${ }^{4}$ E.g., Mihail Bulgakov, Milan Kundera, Bohumil Hrabal, Danilo Kiš, Ismail Kadare, Ivan Klíma, Milorad Pavič.
} 
Finally, to register the present study as part of world literature research, it can be added that the appearance of the novels mentioned is not only a matter of genealogy or of limited, national causality justifiable by the internal evolution of Romanian literature, but belongs instead to an extensively drawn map of the global phenomenon.

\section{Incipient Typological Frames and Correspondences}

The first forms of magical realism have been connected to the new geopolitical configurations that appeared "in this border-zone of Europe, where it functions either as a compensatory, or as an illuminating, vision of brutal and unaccountable historical circumstances (mainly before and immediately after World War II)" 5 .

Indeed, the term had been used with regard to particular tendencies in GermanAustrian and Central European fiction as early as the 1930s. It is worth recalling that most theorists associate the birth of magical realism as a syntagm with Franz Roh's 1925 essay, as applied to the fine arts domain. Roh highlights, on the one hand, the return of painters to realism, in line with the Neue Sachlichkeit trend, yet representing a "new realism" marked by the passage through expressionism, this merger of grotesque reality and a metaphysical perspective ${ }^{6}$. On the other hand, magical realism uncovers the mystery that "does not descend to the represented world, but rather hides and palpitates behind it" . Thus, magical realism ends up absorbing aspects of what Russian Formalists designated as "defamiliarization". The European novelists theorizing about magical realism, starting from Roh, while also writing fiction in this manner, were Ernst Jünger and Massimo Bontempelli. The German writer is known for the commitment to retrieving the magic that hides in things, aiming, therefore, at the reconciliation of German romanticism with modern technology. Meanwhile, the Italian writer ${ }^{8}$ embraces "the other dimension" which opens mythical and magical perspectives on reality, seeking a consciously entertained primitivism capable of reconciling the everyday and the miraculous. In the novels of the first phase of European magical realism, spatial dislocations structure the narrative in accordance with initiatory experiences. Plots contain several epiphanies and potent symbolically charged events. Thus, the magical

\footnotetext{
5 Cristina Șandru, Worlds Apart? A postcolonial Reading of post-1945 East-Central European Literature, Newcastle upon Tyne, Cambridge Scholars Publishing, 2012, pp. 148-149.

${ }^{6}$ Kenneth Reeds, What Is Magical Realism? An Explanation of a Literary Style, New York, Edwin Mellen Press, 2012, p. 47.

${ }^{7}$ Franz Roh, in Lois Parkinson Zamora and Wendy B. Faris (eds.), Magical Realism. Theory, History, Community, Durham - London, Duke University Press, 1995, p. 16.

${ }^{8}$ Massimo Bontempelli's best known novel containing clear magical realist elements is Gente nel tempo (1937), translated into Romanian as Oameni în timp, in 1968.
} 
realist aesthetic programme aims at inventing fresh myths capable of renewing the cultural atmosphere.

In the same period, Romanian literature was bent on synchronizing with the artistic modernism of Europe, while writers engaged in a prolific debate arising from the question of "why we fail to have novels". By launching new fictional formulae, they tried to fill in the existing gaps with texts that deviated from traditional realism. Consequently, it becomes impossible to label clearly, as either realistic or fantastic, Mihail Sadoveanu's or Vasile Voiculescu's short stories, because the typical fantastic hesitation is missing, and the narrative glides imperceptibly between diverse levels, retrieving mythical and archaic aspects of old civilizations.

Here are the principles enunciated in Mihail Sadoveanu's novel Creanga de aur [The Golden Bough] (1933) through the mouthpiece of the intradiegetic narrator, Stamatin: the professor is a scholar lost in lyrical effusions and comes from "the nether world", acting as the guide of "the unknown world", a pristine region "steeped in persistent signs of yore" that "overcome him with a primitive's emotions". Though he is "a scientist", i.e. a geologist, Stamatin opposes to reason "the ability of reaching right into the heart of things"- by what is termed "spiritual cognition". The author returns to an age overlooked by chronicles (the eighth century) in order to write its mythical history. Mihail Sadoveanu weaves into his story of Kesarion Breb landmarks of attested history (the Byzantine Empire in the age of Empress Irina and her son, Constantine, the outcome of the iconoclasts' defeat, the last Nicean Ecumenical Council). The passage from the religion of Zamolxis to Christianity and the esoteric lore belong to another, archaic world and to an alternative world-view that is quite naturally inserted in the overall narrative of the chronicle species. Through its philosophical meditation about world history, the novel ranks - thematically - among the magical realist texts. The blurring of frontiers between history, legend, myth and fantasy, which prevents readers from knowing where they are unless they constantly confront the text of the novel with historical sources, recommends this narrative both as miraculously realistic (i.e. tantamount to the ontological species of Latin-American magical realism, in whose view reality is magical in itself) and as epistemological (according to the European brand of magical realism, for which magic derives from the intensity of the outlook that "alters" reality $)^{10}$. Although the narrative is interspersed with fabulous elements (the Prince, the charmed slippers, Cinderella) ${ }^{11}$ and with overlapping identities (Old Woman Teosva/ the future empress Maria), the fairytale frame

\footnotetext{
${ }^{9}$ Mihail Sadoveanu, Creanga de aur [The Golden Bough] (1933), București, Minerva, 1976, pp. 5-10 passim. When not specified otherwise, the English translations from Romanian are mine.

${ }^{10}$ The classification was proposed by Christopher Warnes, Magical Realism.

${ }^{11}$ Nicolae Manolescu, Arca lui Noe. Eseu despre romanul românesc [Noah's Ark. An Essay about Romanian Novel], București, 1000+1 Gramar, 2001, p. 607.
} 
gradually turns into a novelistic structure, as the hero, Kesarion Breb, gets to experience regret, impasse and tragedy.

\section{Romanian Magical Realist Novels of the Communist Period}

Unfortunately, the natural interwar dynamic and diversity of fictional formulae, which included experiments at the periphery of canonical realism, were cut short by the political upheaval and the official proletcultist ideology - with socialist realism as the literary expression of what was envisaged as the role of fiction in the service of the new regime, a satellite of the USSR. It was therefore only in the 1960s that a new generation, later to be assimilated to neo-modernism, took the stage. Taking advantage of the cultural effects of partial liberalization, the new themes and codes of the fiction writers in the 1960s and 1970s (Ștefan Bănulescu, George Bălăiță, D.R. Popescu) allowed revisiting traditional realism through transfigured reality representations "with fantastic and mythical reflexes" 12 . We beg to differ from Denning's interpretation of global magical realism as the direct heir of the twenties' and thirties' proletcultist literature ${ }^{13}$ : the new Romanian realism of the 1960s represents instead an evasive reaction to the dominant discourse of socialist realism, alongside fantastic, allegorical and experimentalparabolic fiction ${ }^{14}$.

In a totalitarian society that censured realistic representation and manipulated "realism" to make it illustrate the socialist utopia - in ridiculous contrast with the actual realities - literature sought a new code capable of avoiding the stale official commonplaces, one that was dedicated to marginality and exceptions instead of exemplariness, while the language used was metaphorical, refusing clichés, as in the fiction of Ştefan Bănulescu, Sorin Titel, D.R. Popescu, Fănuș Neagu and Nicolae Velea. This prepared the vernacular ground for absorbing the new magical realist influences from Latin America. What does justice to Denning's thesis, however, is the (paradoxical) fact that the influences which contributed to reshaping Romanian fiction in this period derived from the same sources which had imposed socialist realism. Because it wished "to create an alternative space, in contradistinction to the Western world, the Soviet Union encouraged, in the minor cultures annexed by it, the creation of an alternative literature, whose names

\footnotetext{
12 Eugen Negrici, Literatura română sub comunism [Romanian Literature under Communism], $3^{\text {rd }}$ edition, Iași, Polirom, 2019, p. 309.

${ }^{13}$ Michael Denning, “The Novelists' International”, in Franco Moretti (ed.), The Novel, p. 706.

${ }^{14}$ Marcel Corniș-Pope ("From Alternative Forms of Realism to Post-Realism: Transitional Literature in the East-Central European Region in the 19th and 20th Century", Serbian Studies Research, 3, 2012, 1, p. 43) maintains that, alongside canonical realism in Central Europe, alternative forms of realism emerge, connected to the regional needs; for Romanian literature, he selects the magical realism of the 1960s, after the psychological realism of the 1930s and preceding the lyrical realism of 1970 women-writers, the hyper-realism of the 1980 s and its postcolonial version of the 1990s.
} 
reshaped the common background previously present in the area"15. While renouncing ideological literary criticism and gobbledygook, the program of translating peripheral literatures dictated by Moscow introduced Romanian literature, as early as the end of the 1950s, to fiction created by foreign writers in various decades, which caused a species of synchronous levelling ${ }^{16}$. As noted by Ilinca Ilian, "the main Latin-American boom writers had been present in Romanian literature ever since the period when they attained popularity in their countries of origin or in the West" ${ }^{\prime 17}$.

Starting with 1967 and well into the beginning of the 1980s, Gabriel García Márquez's short stories and novels continued to be translated, including One Hundred Years of Solitude (1979); in Ángel Rama's view, this was "the symbolbook which gave the boom consistence while it was still fluid, shaping it definitively but also freezing it, to a certain extent, and allowing it to begin waning"18. Naturally, the simultaneous reception of the Latin-American boom in Romania involved an influence on the auctorial vision, on major themes and specific narrative techniques. This caused a genre scarcely present in our country in the interwar period to be successfully appropriated by "the new wave of writers who were themselves derived, from indigenous barbarian communities"19.

Romanian magical realism acquired subversive accents as it evolved from the short fiction debuts to the novels of the 1970s. Unable to represent in the realistic code the horrors of totalitarianism, magical realism described the world obliquely, allusively twisting history - in narratives that "naturalized the marvelous interwoven with historical trauma" 20 . This evolution can be followed in the chronological reading of Sorin Titel's work, for example: from the innocent look of the child discovering the world in the short stories of his debut, the author veered

\footnotetext{
${ }^{15}$ Ștefan Baghiu, "Traducerea romanului în România realismului socialist. De la centrul ideologic la marginile geografice" ["Translating the Novel in Realist Socialist Romania. From the Ideological Centre to the Geographic Limes"], Vatra, 41, 2016, 3-4, pp. 89-114. For the English version see Ștefan Baghiu, "Translating Novels in Romania: The Age of Socialist Realism. From an Ideological Center to Geographical Margins”, Studia Universitatis Babeș-Bolyai Philologia, 61, 2016, 1, pp. 5-18.

16 Ángel Rama, apud Ilinca Ilian, "Destinul literaturii latino-americane în România regimului comunist (1948-1989)" ["The Destiny of Latin-American Literature in Communist Romania"], Philologica Jassyensia, 15, 2019, 1, p. 168.

${ }^{17}$ Ilinca Ilian, "Destinul literaturii latino-americane în România", p 175. This article chronicles in detail the translations of this period; we encounter prominent names present in today's magical realism anthologies: Arturo Uslar Pietri, Alejo Carpentier, Miguel Angel Asturias, Carlos Fuentes, Mario Vargas Llosa, Gabriel García Márquez, alongside writers of the proto-boom - as they were termed by Donoso - Borges, Saramago, Cortázar.

${ }^{18}$ Angel Rama, apud Ilinca Ilian, "Destinul literaturii latino-americane în România”, p. 173.

${ }^{19}$ Eugen Negrici (Literatura română, p. 310) offers a double explanation: firstly, a socio-political one (liberalization; a way of giving a sharp retort to socialist realism; the recovery of the autochthonous background, which amounted to a return to national identity, after the previous decade's Stalinization); secondly, a cultural explanation: filling in the unoccupied interwar slots.

${ }^{20}$ Mariano Siskind, "The Genres of World Literature", p. 353.
} 
towards creating a fabulous domesticity: Eva Nada's world in Țara îndepărtată [The Remote Country] (1974), subsequently writing experimental fiction, very much in the Kafkian absurd vein in Noaptea inocenților [The Innocents' Night] (1970) and in Lunga călătorie a prizonierului [The Prisoner's Long Journey] (1971). Magical realism resorted to specific defamiliarization techniques (e.g. repetitions, literalization of metaphors) in order to emphasize the non-representable at the heart of reality - which lent a grotesque nuance to the genre ${ }^{21}$. Totalitarian regime carnivalization in Latin-American novels had its counterpart in CentralEurope, where:

...magical realism can best be described as a mode of aesthetic interrogation arising in cultural and ideological contexts variously marked by political and epistemic violence. It speaks in the forked tongue of ebullience and restraint, involvement and detachment, nostalgia and irony ${ }^{22}$.

In this second phase, magical realism did not differ from miraculous realism as defined by Carpentier (presupposing a magical reality per se); it acted as a genre representative of liminal spaces, haunted by political violence, characteristic of transitional periods and critical moments. We feel we can propose that ontological and epistemological perspectives merged in autochthonous magical realism in the 1960s. Mythical coherence attempted to make absurd contemporary history meaningful, drawing on archaic elements in the background, while defamiliarization and neo-modernist fiction techniques served to secure the literary representability of what lay at the heart of a delirious totalitarian reality impossible to represent.

Although there are hardly any new local definitions of magical realism, we can identify quite numerous and differing illustrations of the genre in Romanian literature under communism, which have been actively received and commented upon as such by specialised literary criticism. Apart from exegeses dedicated to Latin-American literature, literary reviews increasingly often resorted to associations of local voices with Latin-American writers, though sometimes retroactively. The inclination to read literary creations in these terms highlighted the fascination exerted by the genre upon writers and critics alike.

After the publication of his short stories in the 1965 volume, Iarna bărbaților [Men's Winter], Cartea de la Metopolis [The Book of Metopolis] (1977) constitutes the confirmation of Ștefan Bănulescu's genuine fictional talent and his capacity to create autonomous fictive worlds. At the time, and directly after it was published, his novel was regarded as emblematic for vernacular magical realism - a position consolidated by subsequent reprints of the book. The leading critic Nicolae

21 See Cristina Șandru's analysis (Worlds Apart?, pp. 146-168) for Central-Europe, and, for postcolonial literatures, David Danow, The Spirit of Carnival: Magical Realism and the Grotesque, Lexington, The University Press of Kentucky, 1995.

${ }^{22}$ Cristina Șandru, Worlds Apart?, p. 154. 
Manolescu traced the novelist's affinities with Faulkner, and Cornis-Pope considered it "a Danube saga à la Márquez" - though it is worth noting that the Columbian writer's masterpiece appeared in Romanian translation later, in 1979. Professor Paul Cernat regards this book as "a local variant of magic realism that foregrounds spatial and temporal dislocation and gives narrative expression to a world divided between rural and urban, modern and archaic characteristics spanning between two world wars, or losing its identity after 1945, in the first years of Romanian communism" ${ }^{23}$. Bănulescu's fiction has recognizable mythical and fantastic traces inherited from Mihail Sadoveanu, Mircea Eliade, and Vasile Voiculescu; it restores the connections with earlier, interwar literature - in the teeth of the proletcultist hiatus ${ }^{24}$. These recurrences represent the (postromantic) reprocessing of myths and folk beliefs as modern fiction. Also, in response to the strictures of communist history, "Romanian literature tended to make its way into an archetypal space, imbuing the daily scene with subtextual significance of (Biblical, ancestral, historical) myths and symbols, wrapping the historical or social reality in the enchanting aura of another world" 25 .

Bănulescu himself maintained that his fiction described a real world because it resuscitates, in Romanian society, one species of historical memory. But the realistic observation is screened by a mythical-archaic distortion, "a mist that any book badly needs" 26 . This auctorial view of history represents, of course, the major theme which unites magical realist novels. Also, just as Faulkner or Márquez, Bănulescu engenders a mythical geography, represented, in his case, by the "postByzantine South-Eastern province" whose utopian and parodic projection confers "to a chimeric, a-temporal realm [...] the stability of palpable reality" 27 . It is a world seemingly beyond conventional time and space, in spite of the numerous historical landmarks (the first Balkan War, King Ferdinand's land reform), and though the novel is set in the period following the Second World War, there is no trace of communism in the social realities described. Surprisingly enough, the most precise references are to the history of Byzantium, an already effete empire more than 500 years ago (This goes to prove or rehearse the above notation about the

\footnotetext{
${ }^{23}$ Paul Cernat, "The Imaginary Kingdom of Ştefan Bănulescu”. Translated by Kevin McCarthy and Jean Harris, in The Observer Translation Project, 2008, http://translations.observatorcultural.ro/TheImaginary-Kingdom-of-\%C4\%B9\%C5\%BEtefan-Banulescu*articleID_21-articles_details.html.

Accessed December 10, 2020.

${ }^{24}$ This is echoed by the debate, in Germany or Austria, around the importance of magical realism as a literary history concept capable of bridging the discontinuity produced by the war and the holocaust and of supporting an alternative literary history that no longer considers the year 1945 as a landmark, as "the zero year", or Nullpunkt, Stunde Null, but offers instead a continuity paradigm.

${ }^{25}$ Vali Dogaru, "Utopia controversată sau trăită a cotidianului" ["Controversial or Experiential Everyday Utopia"], Vatra, 35, 2005, 5-6, pp. 105-108.

${ }^{26}$ Ștefan Bănulescu, Cartea de la Metopolis [The Book of Metopolis], $3^{\text {rd }}$ edition, București, Allfa, 1999 , p. 26.

${ }^{27}$ Eugen Negrici, Literatura română, p. 465.
} 
mythical or archetypal modulations as escapes from the terribly humiliating, dehumanizing everyday life under communism). Actually, history is constantly given a mythical turn, being ascribed to "a dishevelled old time, with mane and hoof besmirched with mud" 28 . Because it is parodied, altered by event and character reduplications and returns, until it becomes impossible to tell what is truth and what is mere fabling, one is justified in understanding that the narrated events belong to a downgraded mythical time, similar to the post-apocalyptic time rendered by the future in the past in the masterpiece of Márquez.

Notably and paradoxically, the fact that immediate history is overlooked leads to the hypertrophy of "historical consciousness": the inhabitants of Metopolis are obsessed with historical certification meant to make them memorable; they run away with the idea that "they genuinely are direct heirs of the imperial Byzantine Romans" 29 . Because they keep spinning micro-narratives that oppose a spurious proto-history to real history, Metopolisians are the diminutive reflection of a national compulsion to lie, especially detectable in the real protochronistic delirium or personality cult of the state leader in the last decades of communism, paralleled by the grotesque carnavalization of the past in Bănulescu's novel.

The mythical doubling of "historical consciousness" makes the Book of Metopolis reflect the Good Book in presenting the outlines of a world from Genesis to the Apocalypse, as do most magical realist novels; but, much like in Márquez's universe, one can already discern terminal signs in the dawning world which announces a pattern of double destruction: in the underground, the hill is blown up to quarry for marble - which transforms the city into a catacomb ("Metopolis lived on eating up its hills" ${ }^{\text {"30}}$ ); at the surface, "trading in years" makes old women sell their remaining lives for the improbable help of some opportunist strangers.

The narrator stages a devouring, grotesque double: firstly, at the surface, the historical parody that opposes "a Byzantine fairyland" to real history, and secondly, underneath, the (economic, as well as moral) "siege" infects the city from below, from the city catacombs ("The inhabitants underneath got wind of everything that happened above and besmirched it all" ${ }^{31}$ ). This corresponds to the Janus Bifrons nature of the carnivalesque singled out by Danow as a major feature of global magic realism ${ }^{32}$.

If the novel is given a subversive reading, as suggested by Cristina Şandru, its hypercoded discourse would signal the return of the repressed to an externally normalized and realistically anchored society. This is signalled by the presence of the miraculous event at the heart of tumultuous history and by the looped projection of the normally linear historical flow. Quite similar to what happens in

\footnotetext{
${ }^{28}$ Ștefan Bănulescu, Cartea, p. 147.

29 Ibidem, p. 48.

${ }^{30}$ Ibidem, p. 31

${ }^{31}$ Ibidem, p. 154.

${ }^{32}$ David Danow, The Spirit of Carnival.
} 
Mikhail Bulgakov's Master and Margarita (1967), miraculous epiphanies bring to light "the intrusion of the unexplainable [which] reveals the irrational at the heart of socialist hyperrationality, its profoundly destructive nature, and the layer of totalitarian madness under the skin of normality"33. Just as Bulgakov or Márquez, Bănulescu invites a stratified reading, simultaneously historical and symbolic, political and metaphysical, mimetic and self-referential ${ }^{34}$.

Similarly to Bănulescu or the Latin-American writers, D.R. Popescu sets up a spiritual territory in Romanian fiction, "a world with a magmatic collective memory at its centre" ${ }^{\prime 35}$. Bent on describing the atrocities of the communist regime in his novels of the $F$ cycle (1969-1976), he resorts to temporal discontinuities, polyphony, multiple perspectives, the erosion of causality and succession. We can identify in all these the typical insertion point of magical realist fiction in the realhistorical setting, where reality is abnormal and its representation becomes problematic and pressing at the same time, blocking a realistic type of reading. Stories about small communities uncover the farce of history and its destructive play, with character and discourse buffoonery ${ }^{36}$; the result is grotesque, bearing pale traces of magic in the appearance of unusual, often monstruous, or pathological, characters. Perched high up in a poplar, walking on stilts, literally rotting on two legs, former circus performers masquerading as political leaders D.R. Popescu's characters make up a vast bestiary, a world held captive behind the cruel lens of a disenchanted look ${ }^{37}$.

In the same large category of novels seeking an alternative code to canonical realism with interspersed magical realist epiphanies we can place Lumea în două zile [The World in Two Days] (1975), by George Bălăiță. This author also creates fiction informed by the ambiguation and obfuscation of the message. Life seems presented from the standpoint of a realistic observer, but it actually hides enigmas and symbols at every turn. There is a remarkably easy alternation of sombre and burlesque registers, rendering the implausible natural and the miraculous domestic, or "causing the demonic to burst forth from soothing, ritualized everyday life" 38 . We identify here the casual oscillation between extremes of magical realism, with the author's style in the background "seeking with morbid voluptuousness to experience the sensitive detail with vicious intensity and project it next as fantasy, thus forcing it to become an enormity and a farce" ${ }^{39}$; by a reverse effect, the resulting hyper-realism can become implausible for the reader, despite being cast in the discursive form of a judicial inquiry. Absorbed into a mythical dimension never

\footnotetext{
${ }^{33}$ Cristina Șandru, Worlds Apart?, p. 159.

${ }^{34}$ Ibidem, p. 161.

${ }^{35}$ Eugen Negrici, Literatura română, p. 471.

${ }^{36}$ Ibidem, pp. 470-471.

${ }^{37}$ Nicolae Manolescu, Arca, p. 653.

${ }^{38}$ Eugen Negrici, Literatura română, p. 474.

${ }^{39}$ Ibidem, p. 475.
} 
absent from magical realist fiction, George Bălăiță's universe is inwardly divided between two simultaneously banal and densely symbolic days (the winter and summer solstice), two spaces (Albala and Dealu Ocna) with two distinct worldorder configurations (the domestic paradise and Moiselini's hellish pub). The novel's diminutive world, mirroring the large scale one, becomes ludicrous, manned by banal bureaucrats and larva-like creatures - a world completely unprepared for miracles; here, the outburst of magic, if anything, causes suspicion, and tragic fears are treated as burlesque. "Parabolically, the novel constructs the human soul as double and contradictory, banal and extraordinary, submissive and rebellious, this-worldly and diabolical" ${ }^{\prime 0}$; Antipa, the protagonist, illustrates all this as "the clerk of nothingness" conjoined contraries and the incompatibility between the what and the how of narrating, the domestic is here conveyed with solemnity while death is grotesquely dawdled away with. Fairytale elements and mythical remainders are revivified though usually on a parodic note, in keeping with the typical magical realist irreverence, and associated later, in the immediately following period, with postmodernism.

Indeed, the nineteen-eighties stand out because of the overlap of postmodernism with the last decade of communism. It is the age of textualist games overlying subversively allusive language. "The assertion of the hubristically assumed right to override official history" 42 recurs in statements of the self-styled postmodern fiction writers. They write alternative histories which deconstruct "unrepresentative" moments, after parodying or rendering them ambiguous as the strategy for ignoring History - manipulated in official parlance by the party's ideological harnessing of national myths. In contrast with the resulting mythography intended to pass for historical truth, the novels of the 1980 generation openly acknowledge their fictitiousness and engage in a subtextual dialogue with official discourses. Just as Bănulescu avoided post-war realities by subversively superimposing on them his "Byzantine miracles", the 1980 generation novelists symptomatically choose the drab and the peripheral. In Ioan Groșan's novel $O$ sută de ani de zile la porțile Orientului [One Hundred Years at the Gates of the Orient] (1992), ridiculous incidents replace the expected chronicle of Voivode Stephen the Great's valiant deeds by immensely funny allusions to Nicolae Ceaușescu's socalled Golden Age. Such repeated instances of gliding between past and present (facilitated by metafictional editing), the heroization of banality, the literalization

\footnotetext{
40 Nicolae Manolescu, Arca, p. 659.

${ }^{41}$ George Bălăiță, Lumea în două zile [The World in Two days] (1975), $6^{\text {th }}$ edition, București, Cartea Românească, 2002, p. 347.

42 Adrian Oțoiu, Ochiul bifurcat, limba sașie. Strategii transgresive în proza Generației 80 [The Bifocal Look, the Squinting Tongue. Transgressive Strategies in the Fiction of the Eighties], Pitești, Paralela 45, 2003, p. 34.
} 
of national-socialist clichés in the gobbledygook of the Ceausescu-age ${ }^{43}$ illustrate a new facet of autochthonous magic realism.

Ștefan Agopian is a writer hard to classify as he exhibits, in a number of novels with magical- realist elements ${ }^{44}$, "the gap between documentary pretexts and fictive formations" 45 , in other words, precisely what traditional historical fiction withholds. In his novels, the realistic illusion misfires due to copious anachronisms; historical information "melts down" into fabulous stories that follow mythical patterns and feature both plausible and Biblical characters (e.g. Tobit, Sara) engaged in actions alongside supernatural apparitions. "Cruel historical happenings are narrated distractedly, with no variations, absent-mindedly, as if already experienced beforehand [...], seen from a distant vantage point" ${ }^{\prime 4}$. The magical realist joining of opposites is associated in his discourse with oxymorons, lyricism, stylistic sumptuousness, while "the grotesque is fused with the sublime, the spiritual with the visceral, the angelic with the demonic, the real with dreams, appearance with essence, death with life, fiction with history" ${ }^{27}$.

Mircea Nedelciu's second novel ${ }^{48}$ stands out due to its subversive approach to the official and utopian socialist realism discourse and it has been read as a therapeutic "fabling treatment applied to reality - a sort of counter-utopia with respect to the Orwell-like dystopian actuality of the year nineteen eighty-four in Romania" ${ }^{49}$. Besides the presence of the typically postmodernist myth of irony and irreverence, this "baroque fantasy" (in the author's own description) confronts readers with apocalyptical scenes resembling those of Bănulescu, D.R. Popescu or Bălăiță, which disrupt and transform utopia into carnival. The gipsy band, along with the ruin of the utopian society, recalls Marquez's nomads, showing up to mark the downgrading of urban Macondo. As in One Hundred Years of Solitude, the present is overlooked in order to take refuge in the past, as individual time withdraws from historical time. What defines autochthonous magical realism is "the desire to survive in fiction and die in reality" ${ }^{50}$. Șandru sees this as conducive

${ }^{43}$ Similar to the magic-realist effects in Milan Kundera's Book of Laughter and Forgetting (1979) or The Joke (1967).

${ }^{44}$ Tache de catifea [Velvet Taki] (1981), Tobit (1983), Manualul întâmplărilor [The Textbook of Happenings] (1984), Sara (1987).

45 Adrian Otoiu, Ochiul, p. 34.

${ }^{46}$ Eugen Negrici, Literatura română, p. 483.

${ }^{47}$ Radu G. Țeposu, Istoria tragică \& grotescă a întunecatului deceniu literar nouă [The Tragic \& Grotesque History of the Dark Eighties in Romanian Literature], $3^{\text {rd }}$ edition, București, Cartea Românească, 2006, p. 222.

${ }^{48}$ Mircea Nedelciu, Opere IV. Tratament fabulatoriu [Fabling Treatment] (1984), $4^{\text {th }}$ edition, Pitești, Paralela 45, 2016.

49 Adina Dinițoiu, Proza lui Mircea Nedelciu. Puterile literaturii în fața politicului și a morții [Mircea Nedelciu's Fiction. The Powers of Literature Facing Politics and Death], București, Tracus Arte, 2011, p. 396.

${ }^{50}$ Ibidem, p. 405. 
to "the implosion of the self-contained mythical universe"51 and announcing the later implosions of the mythical universe in Bogdan Popescu's or Mircea Cărtărescu's fiction of the years 2000.

Such grotesquely realistic, deviant forms which responded to socialist realism created irreverent symbolic spaces in a social context opposed to laughter, irony and satire and which, at best, regarded them suspiciously. Irreverence and revolt, together with parodic, baroque hyperbolizations and subversive, polyphonic and eccentric language, place the generic repertoire of Romanian magic realism in line with the global repertoire. Moreover, this points to the way magical realism, in totalitarian societies such as those of Central Europe and Latin America, was expressive of a subversive sensibility which

...operated an enlargement of vision, including in its discourse those elements occulted by the official truth. It thus acted as a virtual corrective to the limited or censored vision of reality most often imposed by authoritarian regimes and constraining worldviews. Its filiations with the counter-tradition of the carnivalesque and its constant subversion of boundaries (whether generic, ontological, or ideological) make it particularly well suited for the expression of a resilient, sceptical form of imagination ${ }^{52}$.

\section{Magical Realist Novels in Post-communism}

Whereas in the first, European modernist phase of magical realism, defamiliarization ranked high, and in the second, Latin-American phase, high modernism and mass culture were reconciled ${ }^{53}$ in combinations of magical realism with postmodern narrative play forms, after 1990, in the third phase, the genre reached its maximum global expansion. The formula was exported by the boom writers to become "the literary language of the emergent post-colonial world" 54 , whether praised or decried for its Western exoticization of the former colonies on the global book market ${ }^{55}$. Magical realism spread its central themes in the newly established culture zones, rewriting local history in opposition to the discourse of Power and in the mythical spirit, resorting to historiographical meta-fiction and carnivalization, with both grotesque and nostalgic expressions.

Romanian culture has fixed its attention upon international debates so as to adopt and adapt them, producing consistent studies that inquire into the postcolonialism-post-communism parallels and the ways postcolonial theory interacts with the complexities generated by the communist experience. The postcolonial outlook has made manifest certain common aspects to be found in Central-

\footnotetext{
${ }^{51}$ Cristina Sandru, Worlds Apart, p. 165.

${ }^{52}$ Ibidem, pp. 167-168.

${ }^{53}$ Franco Moretti, Modern Epic. The World System from Goethe to Garcia Márquez, New York, Verso, 1996, p. 235.

${ }^{54}$ Homi Bhabha, Nation and Narration, London, Routledge, 1990, p. 7.

55 David Damrosch, How to Read World Literature, Oxford, Wiley-Blackwell, 2009, pp. 106-107.
} 
European and postcolonial novels: liminality, ambiguous cultural identities, textual ambivalence, cultural fragmentation and discursive violence ${ }^{56}$. Cornis-Pope notes that

...much of the post-1989 literature has been concerned with the breakdown of people's sense of the "real" - already badly compromised by the communist propaganda but subsequently diluted even further by the "hysteria of the production and reproduction of the real" (Baudrillard) pursued by some transitional postcommunist governments ${ }^{57}$.

This is what lies behind the sensation that characters in postcolonial and postcommunist novels are unreal, as is the case with Rushdie's or Mircea Cărtărescu's protagonists. To these should be added the generic hybridity - realism, antirealism, surrealism -, the distinctive mark of literature in the new millenium in bestsellers that pose provocation to mimesis and its limits.

As with the evolution of postcolonial literatures, the literature created in excommunist countries gives priority to fictional representations that counter official History with differing individual versions. Substituting to world-history the history of micro-communities centred around protagonists at the same time pivotal and peripheral has been a theme common to novels by Mircea Cărtărescu (Orbitor [Blinding], I-III, 1996-2007), Bogdan Popescu (Cine adoarme ultimul [Whoever Falls Asleep Last], 2007), Doina Ruști (Fantoma din moară [The Phantom in the Mill], 2008), Radu Pavel Gheo (Noapte bună, copii! [Good Night, Children!], 2010), Tudor Ganea (Cazemata [The Casemate], 2016). Having spent their childhood under communism, the authors write, after 1990, novels depicting an age, at the same time exorcising historical trauma and writing down their autobiographies by self-reflexive fiction. Speaking from a fairly comprehensive community perspective, they are in a position to tell the truth about this age, though they feel torn between two worlds and need to acknowledge both the cruelty of historical fact and the aura of nostalgia, something that makes them oscillate between horror and fascination, hopefulness and powerlessness, compelling them to speak in double language, to alternate wondrous and grotesque expressiveness, irony and sarcasm. Their thematic repertoire and narrative techniques rank these novels among exemplary titles that represent the postcolonial expansion of magical realism: Salman Rushdie's Midnight Children (1981), Toni Morrison's Beloved (1987), Ben Okri's The Famished Road (1991), Patrick Chamoiseaux's Texaco (1992).

\footnotetext{
${ }^{56}$ Dumitru Tucan, "The Adaptability of Theory: Postcolonialism vs. Postcommunism in Romanian Literary Studies", Dacoromania litteraria, 2015, 2, p. 112.

${ }^{57}$ Marcel Cornis-Pope, "From Alternative Forms", p. 51.
} 
Far from presenting "utopian worlds" that imply exiting history through the front door $^{58}$ as claimed by critic Florin Oprescu, these novels enter history by "forcing the back door" with discursive subversiveness and non-realistic representations; they seek an alternative code to compensate the inability of "historical heterotopias" to reach the essential. To explain the heyday of the magical realist genre in ages and at times of crisis (in the communist decades or the post-1989 society), we must turn to the mythical thought performing the transformation of social change into magic and employing returning archetypes to read and understand the contemporary world. It is possible to extend to the post1989 Romanian context Franco Moretti's belief that the success of magical realism in the great Western metropolises was due to the desire of making sense of modern societies and to their fascination with retelling actual History as an adventure seasoned with miracles ${ }^{59}$ : superimposed on the conflicting official discourse variants, Romanian magical realist novelistic discourse re-writes a re-enchanted history of communism.

Different generations and social classes propose contradictory representations of a supposedly common history in the above-mentioned novels. We witness, in the reproduction of these clashing variants, what Eugene Arva has regarded as the therapeutic staging of memory ${ }^{60}$. Magical realism does not, of course, copy, but naturalizes the marvellous interwoven with estranged social domination, massacres, wars and other historical traumas ${ }^{61}$; the same happens with the Romanian fairytale motifs that show God and Saint Peter lost in the post-1989 transition; they are interwoven with the personal drama of "frontiersmen" failing in their attempt to cross the communist frontier illegally ${ }^{62}$. Magical realism transforms and makes legible a reality that cannot be represented by regarding traumatic imagination aesthetically; it ends up normalizing what cannot be represented ${ }^{63}$.

The approach that simultaneously "undertakes intellectual elucidation and imaginative reconstruction of a contradictory and often violent historical reality" ${ }^{4}$ is situated between history and personal memory, trying to bridge, with the magical realist écriture, the divide between the present writing ego and the past one ${ }^{65}$. Contemplative nostalgia, which Svetlana Boym sees as the defence mechanism to

58 Florin Oprescu, Romanul românesc şi morfologia puterii [The Romanian Novel and the Morphology of Power], Iași, Institutul European, 2018, pp. 215-218.

${ }^{59}$ Franco Moretti, Modern Epic, pp. 249-250.

${ }^{60}$ Eugene Arva, "Writing Trauma: Magical Realism and the Traumatic Imagination", Interférences littéraires, 2014, 14, p. 7.

${ }^{61}$ Mariano Siskind, The Genres, p. 353.

${ }^{62}$ Radu Pavel Gheo, Noapte bună, copii! [Good Night, Children], Iași, Polirom, 2010.

${ }^{63}$ Ato Quayson, "Fecundities of the Unexpected: Magical Realism, Narrative and History", in Franco Moretti (ed.), The Novel, p. 734.

${ }^{64}$ Cristina Șandru, Words Apart?, p. 154.

${ }^{65}$ Denis Walder, "Writing, Representation, and Postcolonial Nostalgia", Textual Practice, 23, 2009 , 6, p. 941 
face historical upheavals in intensely changing ages following revolutions ${ }^{66}$, explains why literary characters, just as members of actual societies in transition, reconstruct their world fictively, while still yearning for the unfulfilled dreams of the past and the obsolete futuristic visions that cause the equally uncertain past and future to haunt the post-communist present. This is precisely what happens when various time segments drift into the fictional universe via the recurring phantommotif (in The Phantom in the Mill by Ruști), via the malefic double (in Blinding by Cărtărescu) or via the sleeping God (in Whoever Falls Asleep Last by Bogdan Popescu). Just as the past haunts - and at times dislocates - the present, the phantom in the above-mentioned novels depersonalizes the characters when penetrating their bodies, blurring the boundary between a human and an alien identity. The persistent phantom-motif embodies the alienating traumatic history effect and ends up exorcising the horrific, guilt-ridden past.

Here are some of the mythical scenario elements in the novels of this magicrealist phase: the foundational moment of archaic communities is set in simultaneously real and fabulous, excellent and abominable locations (Cărtărescu's Tântava and Bucharest; Ruști's Comoșteni, with the mill at the centre, Bogdan Popescu's Saints Village); the end of the world, caused by the totalitarian upheaval, culminates in the apocalyptic downfall - but without the salvation of the Biblical Book of Revelation (though the fall of communism might have been expected to make the post-communist world meaningful): instead, the identity fracture between the two epochs is anarchetypically augmented. The events in the marginal community of the Saints Village ${ }^{67}$ before and after 1989 are completely chaotic and there is no mythical narrative capable of ordering them; foundational myths are presented in downgraded, implausible forms, while in general cultural myths are tainted with (self)irony ${ }^{68}$; the alternative (fabulous or archaic) discourse keeps parodically aloof from the protochronistic official uses of "local" or "national" themes ${ }^{69}$.

\section{Romanian Generic Repertoire Correspondences with Global Magical Realism}

After placing in a global network of magical realist affinities some canonical Romanian novels of the previous century which we have re-read here, it has become possible to group them together chronologically and typologically into three classes or phases of fictional literary works. The first one includes the Romanian fiction by Mihail Sadoveanu and Vasile Voiculescu, corresponding to

\footnotetext{
${ }^{66}$ Svetlana Boym, The Future of Nostalgia, New York, Basic Books, 2001.

${ }^{67}$ Bogdan Popescu, Cine adoarme ultimul [Whoever Falls Asleep Last], Iaşi, Polirom, 2007.

68 See, in Cărtărescu's Blinding (III), the ridiculed personification of revolutionary Romania in Rosenthal's painting.

${ }^{69}$ The foundational story about the male and female Ancestors who built the Saints Village is told to an empty classroom by a constantly drunken schoolmaster purporting to deliver a scientific account.
} 
the magical realist novels by Jünger and Bontempelli. These writers share a taste for strong symbolism, "primitivism", the blurring of boundaries between history, legend, myth and fantasy. We have subsequently grouped together into a second class the novels written under communism by Ștefan Bănulescu, D.R. Popescu, George Bălăiță, Sorin Titel or Ștefan Agopian, directly influenced by the synchronous translations of Latin-American writers. The creation of imaginary kingdoms in the heart of reality, the rewriting of history following mythical patterns from Genesis to the Apocalypse, the use of hypercoded discourse subversively confronting Power, the magical and grotesque carnivalization of the world are some of the landmarks of this phase or class. To them were added in the 1980s, from the postmodernist repertory, the use of metafictional écriture, of (self)irony, polyphony and the multiplication of narrative threads - features to be retained by magical realist novels of post-communism. The books of the Romanian members of the third phase (comprising Mircea Cărtărescu's, Bogdan Popescu's or Doina Ruști's novels) compare favourably with the ones by canonical postcolonial authors' (i.e. Rushdie, Morrison or Ben Okri), as they are written in response to a socio-cultural background similar to the postcolonial. The narrators-characters in these novels, posited as metaphysical chroniclers of the fictional world, confront readers with the macro-themes of history and memory, exacerbate grotesqueness to exorcise the phantoms of a traumatic past and exploit mythical structures anarchetypally, while actually hiding behind their ironically distancing, nostalgic retrievals.

Finally, a number of family resemblances can be mentioned that are shared by all these novels and justifying the world-literary status of the magical realist genre: conjoined wonderment and grotesqueness; the profusely baroque use of oxymorons and hyperbolism; the literalization of metaphors. Features of this kind integrate such novels in the counter-tradition of the Bakhtinian carnivalesque whose "cultural exorcism" renders problematic all traditional representations, facilitating a fresh outlook that defamiliarizes a present equally haunted by spectres of the past and by demons of the future.

\section{BIBLIOGRAPHY}

ARVA, Eugene L., "Writing Trauma: Magical Realism and the Traumatic Imagination", Interférences littéraires, 2014, 14, pp. 5-14.

ARVA, Eugene L., The Traumatic Imagination: Histories of Violence in Magical Realist Fiction, Amherst, Cambria, 2011.

BAGHIU, Ștefan, "Traducerea romanului în România realismului socialist. De la centrul ideologic la marginile geografice" ["Translating the Novel in Realist Socialist Romania. From the Ideological Centre to the Geographic Limes"], Vatra, 41, 2016, 3-4, pp. 89-114.

BAGHIU, Ştefan, "Translating Novels in Romania: The Age of Socialist Realism. From an Ideological Center to Geographical Margins”, Studia Universitatis Babeș-Bolyai Philologia, 61, 2016, 1, pp. 5-18. 
BĂLĂIȚĂ, George, Lumea în două zile [The World in Two days], $6^{\text {th }}$ edition, București, Cartea Românească, 2002.

BĂNULESCU, Ștefan, Cartea de la Metopolis [The Book of Metopolis], $3^{\text {rd }}$ edition, București, Allfa, 1999.

BHABHA, Homi, Nation and Narration, New York, Routledge, 1990.

BOYM, Svetlana, The Future of Nostalgia, New York, Basic, 2001.

CĂRTĂRESCU, Mircea, Orbitor. Aripa dreaptă [Blinding. Right Wing], București, Humanitas, 2007.

CERNAT, Paul, Paul Cernat, "The Imaginary Kingdom of Ştefan Bănulescu”. Translated by Kevin McCarthy and Jean Harris, in The Observer Translation Project, 2008, http://translations.observatorcultural.ro/The-Imaginary-Kingdom-of-\%C4\%B9\%C5\%BEtefanBanulescu*articleID_21-articles_details.html. Accessed December 10, 2020.

CHANADY, Amaryll, Magical Realism and the Fantastic. Resolved Versus Unresolved Antinomy, New York, Routledge, 1985.

CORNIS-POPE, Marcel, "From Alternative Forms of Realism to Post-Realism: Transitional Literature in the East-Central European Region in the 19th and 20th Century", Serbian Studies Research, 3, 2012, 1, pp. 41-58.

CORNIS-POPE, Marcel, NEUBAUER, John (eds.), History of the Literary Cultures of East-Central Europe. Junctures and Disjunctures in the 19th and 20th Centuries, vol. I, Amsterdam Philadelphia, John Benjamins Publishing Company, 2004.

DAMROSCH, David, How to Read World Literature, Oxford, Wiley-Blackwell, 2009.

DANOW, David, The Spirit of Carnival: Magical Realism and the Grotesque, Lexington, The University Press of Kentucky, 1995.

DENNING, Michael, "The Novelists International", in Franco Moretti (ed.), The Novel, pp. 703-725.

D'HAEN, Theo, DAMROSCH, David, KADIR, Dejelal (eds.), The Routledge Companion to World Literature, New York, Routledge, 2012.

DINIȚOIU, Adina, Proza lui Mircea Nedelciu. Puterile literaturii în fața politicului și a morții [Mircea Nedelciu's Fiction. The Powers of Literature Facing Politics and Death], București, Tracus Arte, 2011.

DOGARU, Vali, "Utopia controversată sau trăită a cotidianului" ["Controversial or Experiential Everyday Utopia"], Vatra, 35, 2005, 5-6, pp. 105-108.

DURIX, Jean Pierre, Mimesis, Genres and Postcolonial Discourse: Deconstructing Magic Realism, London, Palgrave MacMillan, 1998.

FARIS, Wendy B., Ordinary Enchantments: Magical Realism and the Remystification of Narrative, Nashville, Vanderbilt University Press, 2004.

GHEO, Radu Pavel, Noapte bună, copii! [Good Night, Children], Iași, Polirom, 2010.

GONZÁLES ECHEVARRÍA, Roberto, Myth and Archive. A Theory of Latin American Narrative, Durham - London, Duke University Press 1998.

ILIAN, Ilinca, "Destinul literaturii latino-americane în România regimului comunist (1948-1989)" ["The Destiny of Latin-American Literature in Communist Romania"], Philologica Jassyensia, 15, 2019, 1, pp. 165-176.

MANOLESCU, Nicolae, Arca lui Noe. Eseu despre romanul românesc [Noah's Ark. An Essay about Romanian Novel], București, 1000+1 Gramar, 2001.

MORETTI, Franco (ed.), The Novel, vol. I: History, Geography and Culture, Princeton, Princeton University Press, 2006.

MORETTI, Franco, Modern Epic. The World System from Goethe to García Márquez, London, Verso, 1996

NEDELCIU, Mircea, Opere IV. Tratament fabulatoriu [Fabling Treatment], $4^{\text {th }}$ edition, Pitești, Paralela 45, 2016.

NEGRICI, Eugen, Literatura română sub comunism [Romanian Literature under Communism], $3^{\text {rd }}$ edition, Iași, Polirom, 2019.

OPRESCU, Florin, Romanul românesc și morfologia puterii [The Romanian Novel and the Morphology of Power], Iași, Institutul European, 2018. 
OȚOIU, Adrian, Ochiul bifurcat, limba sașie. Strategii transgresive în proza Generației 80 [The Bifocal Look, the Squinting Tongue. Transgressive Strategies in the Fiction of the Eighties], Pitești, Paralela 45, 2003.

POPESCU, Bogdan, Cine adoarme ultimul [Whoever Falls Asleep Last], Iași, Polirom, 2007.

QUAYSON, Ato, "Fecundities of the Unexpected: Magical Realism, Narrative and History", in Franco Moretti (ed.), The Novel, pp. 726-756.

REEDS, Kenneth, What Is Magical Realism? An Explanation of a Literary Style, New York, Edwin Mellen Press, 2012.

RUȘTI, Doina, Fantoma din moară [The Phantom in the Mill], Iași, Polirom, 2008.

SADOVEANU, Mihail, Creanga de aur [The Golden Bough], București, Minerva, 1976.

ȘANDRU, Cristina, Worlds Apart? A Postcolonial Reading of post-1945 East-Central European Literature, Newcastle upon Tyne, Cambridge Scholars Publishing, 2012.

SISKIND, Mariano, "The Genres of World Literature. The Case of Magical Realism", in Theo D'haen, David Damrosch, Djelal Kadir (eds.), The Routledge Companion to World Literature, New York, Routledge, 2012, pp. 345-355.

ȚEPOSU, Radu G., Istoria tragică \& grotescă a întunecatului deceniu literar nouă [The Tragic \& Grotesque History of the Dark Eighties in Romanian Literature], $3^{\text {rd }}$ edition, București, Cartea Românească, 2006.

TUCAN, Dumitru, "The Adaptability of Theory: Postcolonialism vs. Postcommunism in Romanian Literary Studies”, Dacoromania litteraria, 2015, 2, pp. 101-116.

WALDER, Denis, "Writing, Representation, and Postcolonial Nostalgia", Textual Practice, 23, 2009, 6, pp. 935-946.

WARNES, Christopher, Magical Realism and the Postcolonial Novel: between Faith and Irreverence, London, Palgrave MacMillan, 2009.

ZAMORA, Lois Parkinson, FARIS, Wendy B. (eds.), Magical Realism. Theory, History, Community, Durham - London, Duke University Press, 1995.

\section{MAGICAL REALISM AVATARS IN THE ROMANIAN NOVEL} (Abstract)

To inscribe Romanian magical realist fiction onto the map of what has turned, from a regional LatinAmerican literary code, into a world literature (sub)genre, we trace the connection of autochthonous novels of the interwar period (marked by the affinities of myth-informed fiction with European literary movements) with the ones of the 1970s and 1980s (featuring direct influences of magical realism from Latin America) and with novels of the 1990s and the years 2000, when the genre came into full bloom globally. Given the novel's remarkably porous fabric, we begin by discussing the uptake and processing of mythical and archaic motifs by Mihail Sadoveanu. To illustrate the fully established genre flourishing in the mid-communist cultural and political context due to ample vernacular translations from the Latin-American boom, we focus on fiction by Sorin Titel, Ștefan Bănulescu, George Bălăiță and Ștefan Agopian, whose writings adapted major magical realist themes in subversively narrative stylistic formats. Four novels by Mircea Cărtărescu, Bogdan Popescu, Doina Ruști and Radu Pavel Gheo are invoked to argue in favour of the post-communist synchronization of Romanian magical realism with postcolonial fiction's postmodernist aesthetics and socio-political accents. Through the importance attached to the topic of memory, to re-writing the past and the problematic positing of recent history seeping into personal histories, the Romanian novels discussed become inscribable in the world literary horizon of magical realism, illuminating its generic repertoire.

Keywords: magical realism, post-communism, subversion, myth, memory. 


\section{AVATARURILE ROMANULUI REALIST-MAGIC ÎN LITERATURA ROMÂNĂ \\ (Rezumat)}

Pentru a urmări integrarea romanului realist-magic autohton în ceea ce a devenit, dintr-un cod regional al literaturii din America Latină, un (sub)gen literar global, propunem construirea unui posibil traseu care conectează, în literatura română, momentul interbelic (al afinităților cu mișcările europene, detectabile în ficțiunile mitice) cu deceniile șapte-opt ale secolului al XX-lea (marcate de influențele directe ale realismului magic sud-american), continuând până în anii 1990-2000, în perioada de expansiune mondială a genului. Întrucât romanul are o porozitate generică accentuată, vom cerceta felul în care anumite proze ale lui Mihail Sadoveanu preiau și modulează atracția pentru mitic și arhaic. Vom urmări apoi, în climatul cultural-politic din deceniile de mijloc ale comunismului românesc, marcate de traducerile ample din literaturile latino-americane, constituirea propriu-zisă a genului, în multiple registre, la prozatori precum Sorin Titel, Ștefan Bănulescu, George Bălăiță, Ștefan Agopian, în romane care dezvoltă, subversiv, prin mărci stilistico-narative specifice, temele majore ale realismului magic. Pentru a argumenta, în postcomunism, sincronizarea romanului autohton cu tendințele din spațiul postcolonial, unde estetica postmodernă a realismului magic se înscrie, de regulă, într-un cadru social-politic, vom analiza patru romane de Mircea Cărtărescu, Bogdan Popescu, Doina Ruști și Radu Pavel Gheo. Prin amploarea temei memoriei, a rescrierii trecutului și a problematizării istoriei recente filtrate în micile istorii personale, romanele românești aduse în discuție se situează în orizontul global al realismului magic, iluminând repertoriul său generic.

Cuvinte-cheie: realism magic, grotesc, postcomunism, subversiune, mit. 